8) B.E. Warren, Phys. Rev. 59, 693 (1941).

J. Biscoe, B.E. Warren, J. Appl. Phys. 13, 364 (1942).

9) R.E. Franklin, Acta Cryst. 4, 253 (1951).

10) H. Akamatsu et al., Bull. Chem. Soc. Japan. 29, 574 (1956).

11) A.J.C. Wilson, Acta Cryst. 2, 245 (1949).

12) A.L. Patterson, Phys. Rev. 56, 978 (1939).

13) A.R. Stokes, A.J.C. Wilson, Proc. Cambridge Phil. Soc. 38, 313 (1942).

14) R.S. Pease, Acta Cryst. 5, 356 (1952).

15) G.H. Burrows, J. Am. Chem. Soc. 46, 1625 (1924).

16) D.R. Dasgupta, B.K. Banerjee, J. Chem. Phys. 23, 2190 (1955).

17) R. Nasini, I. Ageno, Gazz. Chim. Ital. 41, 131 (1911).

18) W.H. Zachariasen, Acta Cryst. 7, 305 (1954).

19) F.E. Wickman, Arkiv. Kemi. Min. Geol. 19 B, 1 (1945).

20) T.D. Parsons, J. Chem. Phys. 34, 2192 (1961).

21) W.H. Zachariasen, Acta Cryst. 5, 68 (1952).

22) P.C.H. Mitchell, R.J.P. Williams, J. Chem. Soc. (1960) 1918.

C. Pecile, Inorg. Chem. 5, 210 (1960).

23) A. Turro, C. Pecile, Nature 191, 66 (1961).

R.A. Otto, L.F. Audrieth, J. Am. Chem. Soc. 80, 5894 (1958).

R.A. Otto, G. Tesi, F.G. Sherif, L.F. Audrieth, J. Am. Chem. Soc. 82, 528 (1960).

24) N.B. Colthup, J. Opt. Soc.Am. 40, 397 (1950).

25) R.I. Wagner, J.L. Bradford, Inorg. Chem. 1, 99 (1962).

M.F. Lappert, Proc. Chem. Soc. (1959) 19.

26) D.W. Aubery, M.F. Lappert, H. Pyszora, J. Chem. Soc. (1960) 5239, (1961) 1931.
27) A.H. Silver, P.J. Bray, J. Chem. Phys. 32, 288 (1960).

28) I.F. Trotter, H.W. Thompson, J. Chem. Soc. (1946) 481.

J. Cymerman, J.B. Willis, J. Chem. Soc., (1951) 1332.

29) M.F. Lappert, Chem. Rev. 56, 959 (1956), ibid., J. Chem. Soc., (1953) 667.

W. Gerrard, M.F. Lappert, Chem. Rev. 58, 1081 (1958), ibid, J. Chem. Soc., (1951) 1020, ibid, Chem. Ind., (1952) 53.

W. Gerrard, M.F. Lappert, J.W. Wallis, J. Chem. Soc., (1960) 2178.

A. Dornow, H.H. Gehrt, Z. anorg. Chem. 294, 81 (1958).

D.W. Aubery, M.F. Lappert., Proc. Chem. Soc. (1960) 148.

30) H.A. Skinner, N.B. Smith, J. Chem. Soc., (1953) 4025.

E.R. van Artsdalen, A.S. Dworkin, J. Am. Chem. Soc. 74, 3401 (1952).

31）学振第 117 委員会, 炭素 36,25 (1963).

32）江木，資源試報告，第57号，(1962). 本田, 豊田, 小林, 菅原, 寺西, 炭素 40, 8 (1967)。

33) C. Coulson, R.T. Taylor, Proc. Phys. Soc. A 65, 815 (1952).

34) R.H. Wentorf, Jr., J. Chem. Phys. 26, 956 (1957); U.S.P. 2,917,617 (Aug. 2, 1960).

35) H.J. Milledge, Nature 184, 715 (1959).

36) I.L. Zagyansky, G.V. Samsonov, J. Appl. Chem. U.S.S.R. 25, 629 (1952).

37) J. Thomas, Jr., N.E. Weston J.E. O'Connor, J. Am. Chem. Soc. 84, 4619 (1963).

(9/7/1968 受付)

\title{
アルカリ土類燐酸塩ガラスの溶解性およびニ，三の物性
}

\author{
金沢牢文・池田正義・川副博司 \\ (東京都立大学工学部工業化学教室)
}

\section{Solubilities and Some Physical Properties of Alkaline Earth Phosphate Glasses}

\author{
By \\ Takafumi KANAZAWA, Masayoshi IKEDA and Hiroshi KAWAZOE \\ (Department of Industrial Chemistry, Faculty of Technology, )
}

Solubilities and physical properties of phosphate glasses in the systems, alkaline earth oxides-phosphorous pentoxide, were measured. Glass systems concerned in the present study are CaO- $\mathrm{P}_{2} \mathrm{O}_{5}, \mathrm{MgO}-\mathrm{P}_{2} \mathrm{O}_{5}, \mathrm{SrO}-\mathrm{P}_{2} \mathrm{O}_{5}, \mathrm{BaO}-\mathrm{P}_{2} \mathrm{O}_{5}, \mathrm{CaO}-\mathrm{MgO}-\mathrm{P}_{2} \mathrm{O}_{5}$ and $\mathrm{CaO}-\mathrm{MgO}-\mathrm{SrO}-$ $\mathrm{BaO}-\mathrm{P}_{2} \mathrm{O}_{5}$. The composition of the glass specimens covered from 0.7 to 1.7 in mole ratio $\mathrm{RO} / \mathrm{P}_{2} \mathrm{O}_{5}$. The subjects tested in this paper are solubility of $\mathrm{P}_{2} \mathrm{O}_{5}$ component in various solvents, chain-length distribution of phosphate ions, mineral composition of the devitrified specimens obtained by heat-treatment, density and refractive index. As the solvents for the 
solubility test, N/2 hydrochloric acid, $2 \%$ citric acid, 10\% neutral sodium citrate, $10 \%$ sodium hydroxide and $10 \%$ ammonium hydroxide etc. were used.

The solubility of $\mathrm{P}_{2} \mathrm{O}_{5}$ in the acid solvents increased with the increase of mole ratio $\mathrm{RO} / \mathrm{P}_{2} \mathrm{O}_{5}$, whereas the reverse change was observed in the case of the basic solvents. It was recognized that the solubility by using the neutral solvents gave a maximum value at a composition of $\mathrm{RO} / \mathrm{P}_{2} \mathrm{O}_{5}=1$. For the sodium hydroxide solvent, $\mathrm{MgO}-\mathrm{P}_{2} \mathrm{O}_{5}$ glass resulted in a considerably high solubility comparing with the other glasses.

The anomalies of some physical properties and solubility in a system $\mathrm{MgO}-\mathrm{P}_{2} \mathrm{O}_{5}$ glass disappeared by adding other alkaline earth oxide to a original system. For instance $\mathrm{CaO}-$ $\mathrm{MgO}-\mathrm{P}_{2} \mathrm{O}_{5}$ and $\mathrm{CaO}-\mathrm{MgO}-\mathrm{SrO}-\mathrm{BaO}-\mathrm{P}_{2} \mathrm{O}_{5}$ glasses had no anomalies concerning density and refractive index curves. When the system contained the mixed alkaline earth oxides, glass formation was observed even in high alkaline earth oxide region. The inclusion of $\mathrm{RO}$ in the melt of a sample up to 1.7 in mole ratio $\mathrm{RO} / \mathrm{P}_{2} \mathrm{O}_{5}$ gave the vitrifaction of the specimen. In these mixed alkaline earth glasses, only two kinds of phosphate ions with short size, i.e. ortho and pyro, were detected by paper chromatographic test and their acid solubilities were higher than those of the other phosphate glasses.

No change in the size-distribution of the phosphate ions was seen in the process of dissolution of the glasses in the various solvents except for the acid solvents in which the hydrolysis of phosphate ions occured considerably and rapidly. It seems that when these glasses are heat-treated and then devitrified no reaction among the phosphate ions arises and the phosphate ions with the various size in the original glass make the correspondingly crystalline phosphates.

[Received Oct. 15, 1968]

\section{1. 緒}

言

燐酸塩ガラスは，その構造と性質の両面からみて，無 機ガラスと有機高分子との中間に位置し，非晶質系の構 造研究のうえで重要かつ有効な物質とみなされる。この 分野の従来の研究では, 主としてアルカリ橉酸塩ガラ スとりわけメタ塩からウルトラ領域にいたる組成に重 点がおかれ，種々の性質の検討が行なわれてきた。それ

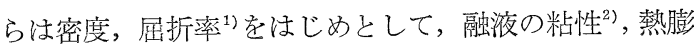
脹率 なな゙かからペーパー・クロマトグラフィーによる縮 合燐酸イオンの分離〕にいたるまで，かなり多岐にわた っている。

一方アルカリ土類燐酸塩ガラスについてみると, 数 件 ${ }^{5) \sim 10)}$ の報告が提出されたていどで,アルカリ系にくら ベて密度，屈折率その他基礎的物性および化学性のデー 夕は豊富とはいえない，そのうえ，しらべられたガラス 組成は，アルカリ系と同様に $\mathrm{RO} / \mathrm{P}_{2} \mathrm{O}_{5}$ (モル比) $\leqq 1$ (以 下 $\mathrm{RO}$ を $\mathrm{R}, \mathrm{P}_{2} \mathrm{O}_{5}$ を $\mathrm{P}$ と略記する) の領域が多く, $\mathrm{R} / \mathrm{P}>1$ の組成のほうはあまり検討されていない， R/P $>1$ の領域はもともとガラス化しにくく，またガラスと しての性質も，たとえば化学的耐久性がわるく一般には 実用的価值にとぼしい。従来あまり研究の力点が括かれ なかったゆえんであろう、しかしガラス構造の本質とく に結晶との構造的関連などを知るうえでは，重視される ベき組成部分と考える.

著者らは燐酸塩ガラス構造究明の資料を提供する意図 のもとに，数種のアルカリ土類鏻酸塩ガラスにおいて修 飾イオンの多い $\mathrm{R} / \mathrm{P}>1$ のガラスからウルトラ領域に いたる組成のものを製造し，諸性質を測定した、アルカ リ土類としては $\mathrm{Ca}, \mathrm{Mg}$ を中心に, $\mathrm{Sr}, \mathrm{Ba}$ および混合
系についても検討した．これらのガラスについて溶㓮溶 解性, ペーパー・クロマトグラフィー, 失透結晶の $\mathrm{X}$ 線 回折図, 密度, 屈折率などを測定検討し, 若干の知見を 得たので報告する。

\section{2. 実験}

\section{1 試料}

試料ガラスを，採用した陽イオン（修飾イオン）の種 類により, $\mathrm{CaO}-\mathrm{P}_{2} \mathrm{O}_{5}(\mathrm{CP}), \mathrm{MgO}-\mathrm{P}_{2} \mathrm{O}_{5}(\mathrm{MP}), \mathrm{SrO}-\mathrm{P}_{2} \mathrm{O}^{5}$ $(\mathrm{SrP}), \mathrm{BaO}-\mathrm{P}_{2} \mathrm{O}_{5}(\mathrm{BP}), \mathrm{CaO}-\mathrm{MgO}-\mathrm{P}_{2} \mathrm{O}_{5}(\mathrm{CMP}), \mathrm{CaO}-$ $\mathrm{MgO}-\mathrm{SrO}-\mathrm{BaO}-\mathrm{P}_{2} \mathrm{O}_{5}$ (CMSrBP) の各系に分類する。 試料の記号を 表-1 亿示した。

ガラス調製のアルカリ土類源としては, 燐酸一水素カ ルシウム (乾燥し無水塩にしたもの), 燐酸一水素マグネ シウム (三水塩)，炭酸ストロンチウム，燐酸一水素バ リウムを用い，燐酸源としては正燐酸液 $\left(82 \% \mathrm{H}_{3} \mathrm{PO}_{4}\right)$ および燐酸二水素アンモニウムとを用いた。燐酸源とし て前者を用いた場合を湿式，後者を用いたときを乾式と する。

R/P が表-1 に示した值になるように原料を秤取し， 十分混合後 $500^{\circ} \sim 700^{\circ} \mathrm{C}$ で 3 6 時閒燒結した. 熔融温 度をきめるためにこれを粉砕してその一部をとり，石炭 灰などの融解点測定法により ASTM 型ゼーゲル・コー ンをつくってあらかじめ原料軟化点を測定した，焼結物 を高アルミナ質坩堝 (CC 印, SSA-H) に入れ炭化珪素 発熱体坩堝型電気炉で, 熔融した. 熔融温度は, 原料軟 化点より $100^{\circ} \sim 150^{\circ} \mathrm{C}$ 上を標準とし時間は 15 40 分間 (多くは 30 分) である. 融液をステンレス板上に流出し 板状のガラスを得た．高 $\mathrm{R} / \mathrm{P}$ 比のものをガラス化する 
Table 1. Composition of glasses and melting temperature of raw materials

\begin{tabular}{|c|c|c|c|c|c|c|c|}
\hline \multirow{2}{*}{$\begin{array}{l}\text { Glass } \\
\text { system }\end{array}$} & \multirow{2}{*}{ Symbol } & \multirow{2}{*}{$\begin{array}{c}\text { Raw } \\
\text { materials }\end{array}$} & \multirow{2}{*}{$\underset{\text { ratio) }}{\mathrm{RO} / \mathrm{P}_{2} \mathrm{O}_{5}}$} & \multicolumn{2}{|c|}{$\mathrm{P}_{2} \mathrm{O}_{5}(\%)$} & \multirow{2}{*}{$\begin{array}{l}\mathrm{RO} \\
(\%) \\
\text { obs. }\end{array}$} & \multirow{2}{*}{$\begin{array}{c}\text { Melting } \\
\text { temp- } \\
\text { erature } \\
\left({ }^{\circ} \mathrm{C}\right)\end{array}$} \\
\hline & & & & theor. & obs. & & \\
\hline \multirow{7}{*}{$\mathrm{CaO}-\mathrm{P}_{2} \mathrm{O}_{5}$} & C 1 & da) & $55 / 45$ & 67.5 & 66.8 & 30.7 & 955 \\
\hline & $\mathrm{C}_{2}$ & $"$ & $50 / 50$ & 71.7 & 70.1 & 28.2 & 940 \\
\hline & C 3 & $"$ & $40 / 60$ & 79.1 & 73.6 & 22.8 & 905 \\
\hline & C 4 & $w^{b)}$ & $55 / 45$ & 68.0 & 68.1 & 30.5 & \\
\hline & C 5 & $"$ & $50 / 50$ & 71.7 & 73.6 & 25.2 & 940 \\
\hline & C 6 & $"$ & $40 / 60$ & 79.4 & 76.3 & 21.0 & 880 \\
\hline & C 7 & $p^{c)}$ & $50 / 50$ & 71.7 & 66.9 & 29.2 & 890 \\
\hline \multirow{6}{*}{$\mathrm{MgO}-\mathrm{P}_{2} \mathrm{O}_{5}$} & M1 & $\mathrm{d}$ & $60 / 40$ & 70.1 & 66.0 & 32.2 & 21295 \\
\hline & M 2 & $"$ & $50 / 50$ & 77.9 & 77.9 & 21.2 & $2 \quad 1125$ \\
\hline & M 3 & $"$ & $40 / 60$ & 84.1 & 79.6 & 19.4 & $4 \quad 1120$ \\
\hline & M4 & $\mathrm{w}$ & $60 / 40$ & 70.1 & 64.9 & 31.6 & $5 \quad 1320$ \\
\hline & M5 & $"$ & $50 / 50$ & 77.9 & 76.3 & 23.3 & 31130 \\
\hline & M6 & " & $40 / 60$ & 84.4 & 79.5 & 19.3 & 1115 \\
\hline \multirow{3}{*}{$\mathrm{SrO}-\mathrm{P}_{2} \mathrm{O}_{5}$} & S 1 & d & $55 / 45$ & 52.7 & & & 1035 \\
\hline & S 2 & $"$ & $50 / 50$ & 57.9 & & & 940 \\
\hline & S 3 & $"$ & $40 / 60$ & 67.3 & & & 935 \\
\hline \multirow{3}{*}{$\mathrm{BaO}-\mathrm{P}_{2} \mathrm{O}_{5}$} & B 1 & d & $55 / 45$ & 43.0 & & & 835 \\
\hline & B 2 & $\Rightarrow$ & $50 / 50$ & 48.0 & & & 840 \\
\hline & B 3 & $"$ & $40 / 60$ & 58.1 & & & 875 \\
\hline \multirow{3}{*}{$\begin{array}{c}\mathrm{CaO}-\mathrm{MgO} \\
\left.-\mathrm{P}_{2} \mathrm{O}_{5} \mathrm{~d}\right)\end{array}$} & CM 1 & d & $60 / 40$ & 66.3 & 63.0 & & 970 \\
\hline & $\mathrm{CM} 2$ & " & $50 / 50$ & 73.2 & 71.7 & & 900 \\
\hline & CM3 & $"$ & $40 / 60$ & 81.5 & 77.8 & & 855 \\
\hline \multirow{4}{*}{$\begin{array}{l}\mathrm{CaO}-\mathrm{MgO} \\
-\mathrm{SrO}-\mathrm{BaO} \\
\left.-\mathrm{P}_{2} \mathrm{O}_{5} \mathrm{e}\right)\end{array}$} & CMSB 1 & $1 \mathrm{~d}$ & $70 / 30$ & 40.7 & 39.6 & & 1000 \\
\hline & CMSB 2 & $2 "$ & $60 / 40$ & 51.7 & 51.1 & & 890 \\
\hline & CMSB 3 & 3 " & $50 / 50$ & 61.7 & 60.4 & & 745 \\
\hline & CMSB 4 & $4 "$ & $40 / 60$ & 70.8 & 66.9 & & 830 \\
\hline
\end{tabular}

a) dry method, $\mathrm{RHPO}_{4} \cdot x \mathrm{H}_{2} \mathrm{O}+\mathrm{NH}_{4} \mathrm{H}_{2} \mathrm{PO}_{4}$

b) wet method, $\mathrm{RHPO}_{4} \cdot x \mathrm{H}_{2} \mathrm{O}+82 \% \mathrm{H}_{3} \mathrm{PO}_{4}$

c) precipitation method, $10 \% \mathrm{NaPO}_{3}+10 \% \mathrm{CaCl}_{2}$

d) $\mathrm{CaO}: \mathrm{MgO}=1: 1(\mathrm{~mol})$

e) $\mathrm{CaO}: \mathrm{MgO}: \mathrm{SrO}: \mathrm{BaO}=1: 1: 1: 1(\mathrm{~mol})$

には，急冷を要するので，一部水冷したものもある。

熔融により予定組成加らの変動, とくに燐酸の揮発, 水分およびアンモニアの残留, アルミナの混入などが予 想されたので, 組成分析ののち, 以後の実験の供試試料 とした. 分析法はアルカリ土類: ETA キレート滴定 法 $^{11)}$, 燐酸 : バナドモリブデン酸法 ${ }^{12)}$, アルミナ：オキ シン比色法 ${ }^{13)}$ である.

なお， $\mathrm{R} / \mathrm{P}=1$ の組成ではアルカリ土類イオンを含む 水溶液と, メ夕燐酸ナトリウム水溶液とからアルカリ土 類のメ夕燐酸塩を沈殿させ，これを原料として愹融しガ ラスをつくることができる。この方法を沈殿法とする. 沈殿法により CP 系では容易に沈殿が生成したが，MP 系では沈殿が生じにくくく被，したがってそれからガラス をつくることができなかった。得られた沈殿は一般に短 鎻燐酸成分を含み，理論組成の $R / P=1$ には必らずしも 一致しない。

\section{2 溶 解 性}

ガラスの化学的性質を調ベる一法として, 肥料の有効 成分測定法を適用し，燐酸分の溶解性を測定した. 100 メッシュ全通の供試ガラスを $100^{\circ} \mathrm{C}$ 乾燥ののち $250 \mathrm{ml}$ メスフラスコに $0.5 \mathrm{~g}$ あるいは $1 \mathrm{~g}$ をとり, 溶片 $75 \mathrm{ml}$ あるいは $150 \mathrm{~m} l$ をそれぞれ加えて天地回転ふりまぜ溶
解を 1 時間行なった(室温 $25^{\circ} \mathrm{C}$, 回転数 $40 \mathrm{rpm}$ ). 溶解

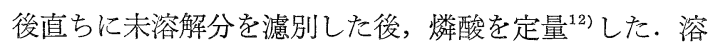
解率は溶解した燐酸量を全燐酸量に対する百分率で表わ す. 使用した溶剤は下の各種である.

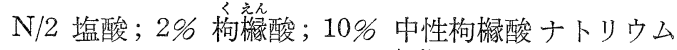
（枸椂酸を少量の水にとかし濃厚苛性ソーダ溶液で $\mathrm{pH} 7$ に調整し，水で希勫する）；10\% 塩化ナトリウム； $3 \%$ 中性 ETA 溶液 (ETA $2 \mathrm{Na}$ 塩を少量の水にとかし, 濃厚苛性ソーダ溶液で $\mathrm{pH} 7$ 亿調整し水で希䣋する); $10 \%$ 苛性ソーダ; 10\% アンモニア水; 水.

\section{3 密度・屈折率}

密度は, 試料ガラスを 180 メッシュ・パスの粉末とし, $\mathrm{P}_{2} \mathrm{O}_{5}$ デシケーター中に 24 時間以上保持してケロシンを 浸液に用いてピクノメーターにより測定した。屈折率は 同しく粉末について浸液法により，アッべ屈折計を用い て測定した.

\section{4 ペーパー・クロマトグラフィー}

ガラス中の橉酸イオンの鎻長 $(n)$ に対する $\mathrm{R} / \mathrm{P}$ 比の 影響, 溶解後のイオンの鎻長分布の経時変化, 溶剤の種 類による $n$ の変化などを検討する目的で, 試料溶解液に ついてペーパー・クロマトグラフィーを実施した。 50 $\mathrm{mg}$ の試料を $20 \mathrm{~m} l$ の $3 \%$ ETA に溶解して約 1/100 モ ルの溶液をつくり, Bernhart-Chess 法 ${ }^{15)}$ B 液により, $18^{\circ} \sim 20^{\circ} \mathrm{C}$ で 10〜14 時間展開した（濾紙: 東洋滤紙 No. $51 \mathrm{~A}$ ). 溶解困難な場合には試料量を少なくしたも のもある. 経時変化, 溶剂の種類の影響の検討に使用し た溶剤は，溶解性の測定に用いたものと同じである，得 られたクロマトグラムのスポットを観察し，それぞれの イオンの含有量の度合を判定した。

\section{5 失透物の $\mathrm{X}$ 線回折}

生成結晶とガラス構造との対応をしらべるために, 加 熱失透物の X線分析を行なった. 100 メッシュ・パスの 粉末ガラスと板状ガラスとを $200^{\circ} \mathrm{C} / \mathrm{hr}$ で昇温加熱し, 矢透がおこったところで加熱をやめ炉冷した。得られた 失透物を粉砕してX線回折 ( $\mathrm{Cu} \mathrm{K}_{\alpha}$ 線)を行なった。

\section{3. 結果と考 察}

\section{1 ガラス組成・原料軟化点}

表-1 に燐酸分の分析值と理論值を, またアルカリ土 類の一部について分析值を示した. なお $\mathrm{R} / \mathrm{P}$ 比はバッ チの值である、試料ガラス全般にわたって燐酸の揮発が みとめられるが， $\mathrm{R} / \mathrm{P}<1$ ではそれはより大きな值を示 している.この組成ではアルカリ土類塩としてではな く, 遊離性燐酸として存在し得る燐酸分があることに起 因するのであろう，ガラス中に含まれる成分として R, $\mathrm{P}$ 以外洘考方礼るのは, アルミナ, 水, アンモニア などである. 分析の結果 $\mathrm{Al}_{2} \mathrm{O}_{3} \quad 0.7 \%$ 程度がみとめら れた。これは熔融に用いた坩堝から混入したものである 
う.

つぎに水の残留が当然考光られる ${ }^{8), 9,10)}$. 表-1 の分 析值をみると，( $\left.\mathrm{RO}+\mathrm{P}_{2} \mathrm{O}_{5}\right)$ の值と $100 \%$ との一致が 悪いものが散見される. 不一致のかなりの部分は，ガラ ス成分上考え得る水であるう. 水の影響は複雑であるこ とが現在知られるに至ったが ${ }^{81,99}$ ，ガラス成分としての 水の役割は，大筋としては塩基成分に類似のもの，すな わち R/P の值を事実上大きくすると考光られる. 並河 $ら^{8), 9)}$ や成瀬ら ${ }^{10)}$ が, 水を $\mathrm{RO}$ とあわせて $\left(\mathrm{RO}+\mathrm{H}_{2} \mathrm{O}\right) /$ $\mathrm{P}_{2} \mathrm{O}_{5}$ のような組成比の扱いを考慮したゆえんであろう. 水の役割を考えるときには成瀬ら ${ }^{10)}$ が指摘するように, 含水量一定のガラスを扱うことが適切である.しかしこ の水の影響は, 本報のとりあつかい範囲に関する限り副 次的なものであるので, ここでの諭議をいちじるしく複 雑なものとしないために，詳細は別のときに扱いたいと 考える.

表-2 に RP 系のガラス化の限界組成值を示した. CM, $\mathrm{CMSrB}$ の両混合カチオン系は，それぞれ単独の R を含 む場合より高 $\mathrm{R} / \mathrm{P}$ 比までガラス化することをみとめた。 その現象は既に混合アルカリ系については見出されてい る ${ }^{16)}$ が，アルカリ土類ではまだ報告されていない。この ことに関しては 3.3 でも触れる。一般的傾向として $\mathrm{R} / \mathrm{P}$ 比大のものほど, 原料軟化点は高くなった.とくに, MP 系が高い值をもつことが目立つ.

Table 2. Glass formation limits in some alkaline earth phosphate systems

\begin{tabular}{|c|c|c|}
\hline System & $\begin{array}{l}\text { aximum } \mathrm{RO} \\
\text { tent for glass } \\
\text { lation (mol\%) }\end{array}$ & Reporter \\
\hline $\mathrm{CaO}-\mathrm{P}_{2} \mathrm{O}_{5}$ & 58 & Takahashi $^{3)}$, Elyard ${ }^{6)}$, Author \\
\hline $\mathrm{MgO}-\mathrm{P}_{2} \mathrm{O}_{5}$ & 65 & Takahashi $^{3)}$, Elyard ${ }^{6}$, Author \\
\hline $\mathrm{SrO}-\mathrm{P}_{2} \mathrm{O}_{5}$ & 56 & Elyard $^{6)}$ \\
\hline $\mathrm{BaO}-\mathrm{P}_{2} \mathrm{O}_{5}$ & 57 & Elyard $^{6)}$ \\
\hline $\mathrm{CaO}-\mathrm{MgO}-\mathrm{P}_{2} \mathrm{O}_{5}$ & $>66$ & Author \\
\hline $\begin{array}{l}\mathrm{CaO}-\mathrm{MgO}-\mathrm{SrO}- \\
\mathrm{BaO}-\mathrm{P}_{2} \mathrm{O}_{5}\end{array}$ & $>70$ & Author \\
\hline
\end{tabular}

\section{2 溶 解 性}

2.2 の測定法では試料ガラスの粒度などの各影響が大 きいから溶解率の数值自体について普遍的論議をするの はをずかしい. しかし大略の傾向を判定, 比較すること はできる。

各種溶剤 (2.2) にたいする P 溶解率とガラス組成との 関倸は, 図-1３のとおりであった。一般に酸性溶剤中 では R/P の大きいほらが溶解率は大きく, 中性液のぼ あい $\mathrm{R} / \mathrm{P}=1$ に近い極大があり,アルカリ液のときは酸 性液とな逆傾向になっていることがわかる.

N/2 塩酸にたいしては, どの系もほとんど耐蝕性をも たず， R の多いものほどよく溶ける. CP はとくに高い 溶解率を示した. 混合系の高 $\mathrm{R} / \mathrm{P}$ ガラスもよく溶解し た. $2 \%$ 枸椂酸についても, ほぼ同様な傾向を示寸が, N/2 塩酸よりも一般に溶解がかんまんになる。
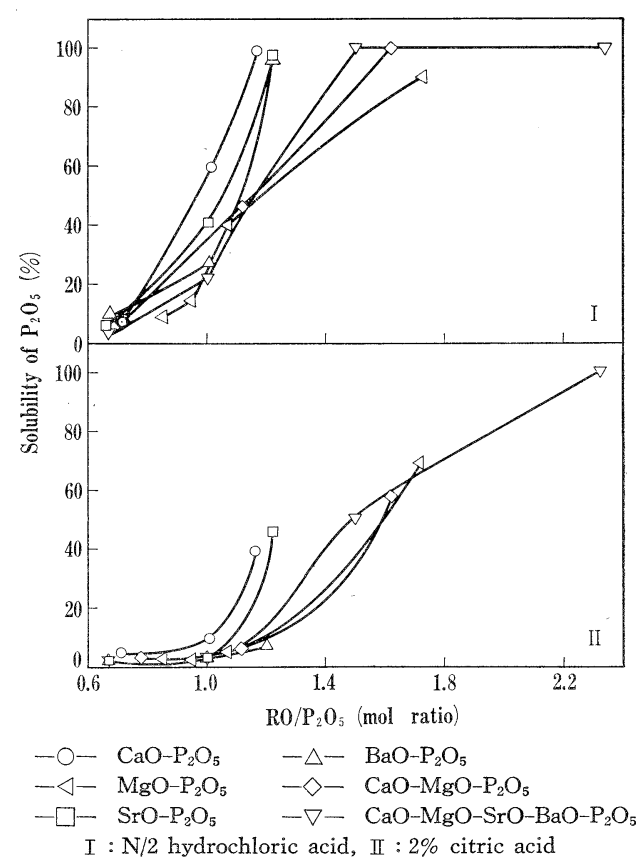

Fig. 1. Solubility of $\mathrm{P}_{2} \mathrm{O}_{5}$ component in acid solvents.

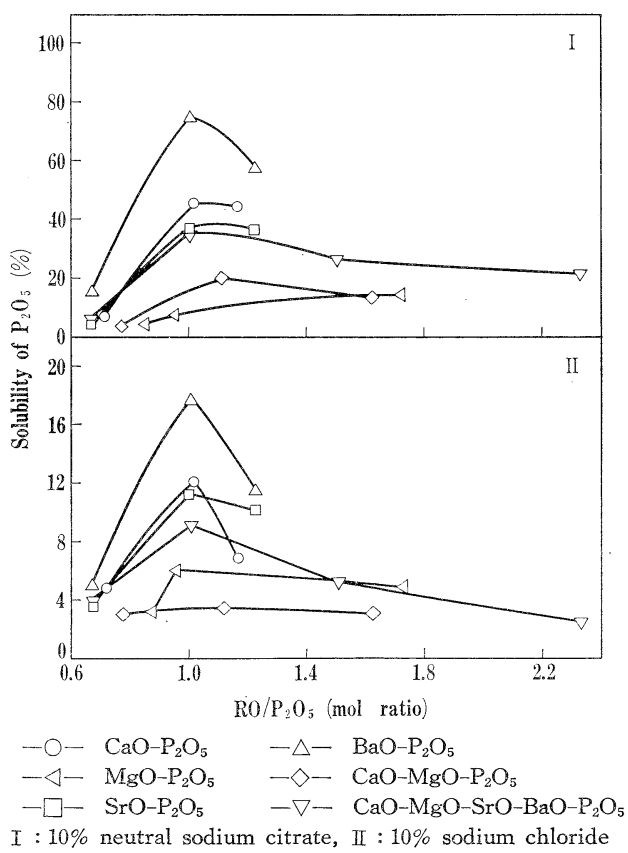

Fig. 2. Solubility of $\mathrm{P}_{2} \mathrm{O}_{5}$ component in neutral solvents.

周知のように, 塩酸による溶解は $\mathrm{H}^{+}$の作用にもとづ き，それの活発な浸入が構造の崩壊分散をま放くのであ る.燐酸イオンが小形で, カチオンが多量にあるほど, 構造の崩壊はより容易になる。上述の傾向がみられるゅ えんである。それにたいし枸椂酸含有液, とくに中性枸 椂酸塩液のほうは, むしろ枸粶酸分による可溶性錯体 ${ }^{17}$ ${ }^{200}$ 生成の作用が主にはたらく，と考えられる，枸粶酸 


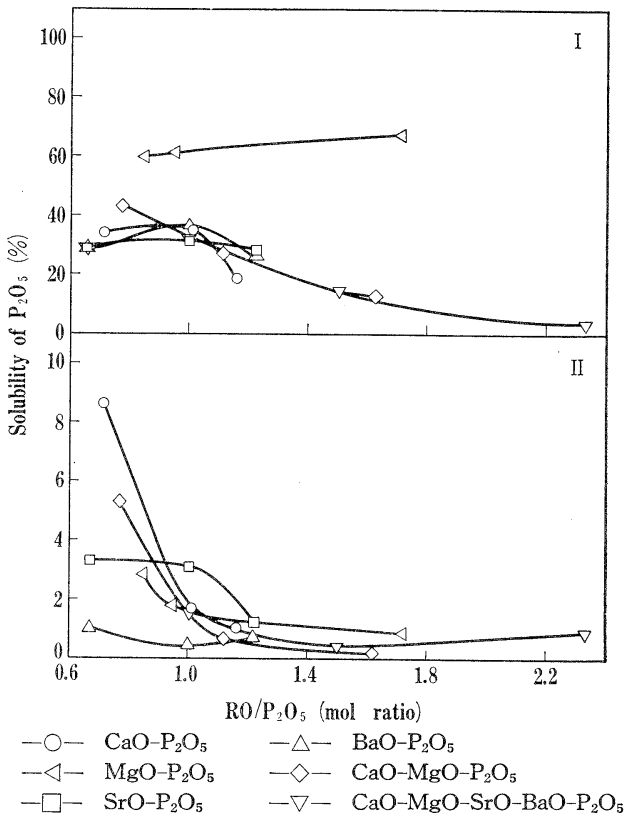

I : $10 \%$ sodium hydroxide, II : $10 \%$ ammonium hydroxide

Fig. 3. Solubility of $\mathrm{P}_{2} \mathrm{O}_{5}$ component in basic solvents.

分による反応は， $\mathrm{H}^{+}$のそれよりもかんまんにす寸む. 栒橹酸分の作用は，それを含む液中で接触する固相の充 填構造性にいちじるしく影響される。すなわち充填した 構造の内部一は，枸粶酸分が十分浸みこむことが困難 で，それだけ枸椂酸錯体が出来にくいから，そのばあい 溶解率は小である, と説明する. $2 \%$ 枸椂酸液において は, 各少量の $\mathrm{H}^{+}$と枸㮕酸基とが溶解力を発揮するの で，塩酸と枸橡酸塩液との中間的な役目をする注ずであ る. 以上の解釈は, 非水溶性肥料塩または関連物質の枸 椂酸溶解性の調查から得られた知見 ${ }^{17) ~ 237}$ に属する.た だしこの説明がはっきり適合しない例外現象もなかには あり，詳細は目下検討をつゔけている。

$\mathrm{R} / \mathrm{P}=1$ に沶いて $\mathrm{CP}$ の溶解率を比較すると塩酸 $>$ 中 性枸栐酸ナトリウム $>2 \%$ 枸椂酸となる。枸椂酸ナト リウム>枸椂酸の関係は, $\mathrm{pH}$ から予測される傾向と 汇逆であるが．これは， $\mathrm{H}^{+}$の役割が少なく，また枸椂 酸濃度の大きいものがその錯体生成の度合も大きい，と して解釈できそうに思える。同心枸椂酸含有液である枸 椂酸溶液と枸椂酸塩溶液とをくらべてみると, 後者の方 において表面構造の影響が大きく, 前者では比較的小さ い, と考える. その意味では $2 \%$ 枸榢酸液は, むしろ塩 酸溶剤のほうに作用効果が近くなってくる場合がある。 そのために，充填構造であるものが枸椽酸溶解性小にな るのでなく, むしろその逆の傾向, すなわち高濃度カチ オン型であるゆえに耐酸性が小になる，という傾向があ たえら机ることになる。図-1 の CP 系, CMSrBP 系 などの枸椂酸溶解率の傾向は，この例であるといえる。

中性枸椂酸ナトリウムにおける anomaly 点より右側
の $\mathrm{R} / \mathrm{P}>1$ の部分の傾向は, $\mathrm{R}$ 増加につれてガラスが ネットワーク構造から充填構造へと変化するが.このば 西い酸性液のときとちがって, 栒椂酸液の構造内部への 浸入作用が拉さえられることの方が強くおこるため，上 解釈したい，酸性溶剤では，このような傾向はない。な お次項 3.3 でも溶解性についてもう一度ふれることにす る.

10\% 苛性ソーダにおいては，N/2 塩酸にたいするの と逆に，一般に R/P 比が大きいほど溶解率小になる. MP が苛性ソーダにかなりの溶解性をむつのは注目す心゙ きである. かような点に $\mathrm{MP}$ ガラスと $\mathrm{SiO}_{2}$ ガラスと の構造的類似がみられる。 $3 \%$ ETA，10\% アンモニア 水にたいしては, この方法では多くは難溶で溶解率は小 さい. $\mathrm{NH}_{4}{ }^{+}, \mathrm{OH}^{-}$によって燐酸顉が切れて固体が溶け るというような現象は存在しないと考える。もしそうで あればガラスがアンモニア水にはよく溶けてよいはずで ある。な扔水にたいする溶解率を測定したが，一般に低 く数％以下にとどまった. R/P 小になるほど水溶率注

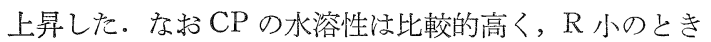
水溶率 $10 \%$ 以上達した。

ここで扱ったような，水にはあまり溶けないが酸液, 中性塩液などの溶剤には溶けやすい，といら型のガラス では，溶解特性とガラス構造との間に対応がみられるの で, 溶解性の検討が意味を持ってくると思う. 溶解性に 関しては,さらに機構的検討を続行中である.

\section{3 密度・屈折率・ガラス体積}

$\mathrm{CMP}, \mathrm{CMSrBP}$ の両混合カチオン系と, 単独の R 含む場合とを比較するために測定を行なった。図-4，5， 6 亿密度, 屈折率および酸素 $1 \mathrm{~g}$ 原子㐫たりのガラス体 積 $\left(V_{0}\right)$ をそれぞれ示した. 各系とも密度と屈折率とは それぞれ組成におうじて同じ傾向の変化を示す。すなわ ち R/P 増大とともに密度および屈折率注大きくなる。

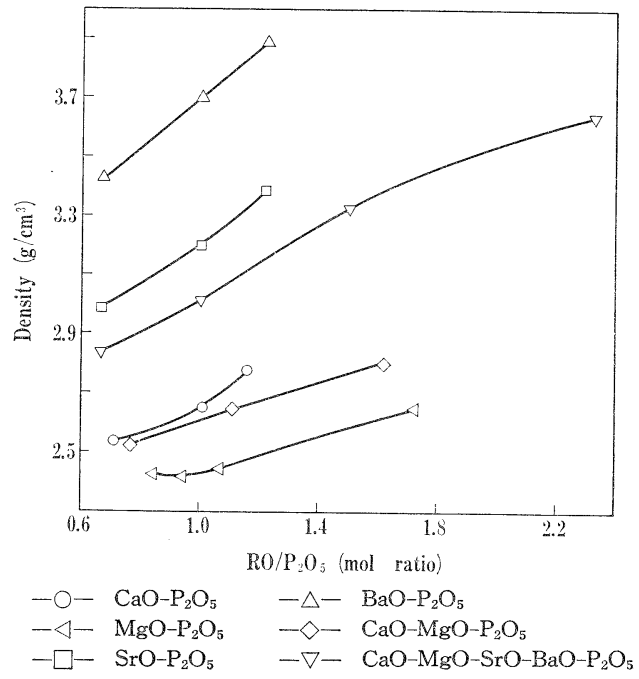

Fig. 4. Density of some alkaline earth phosphate glasses. 


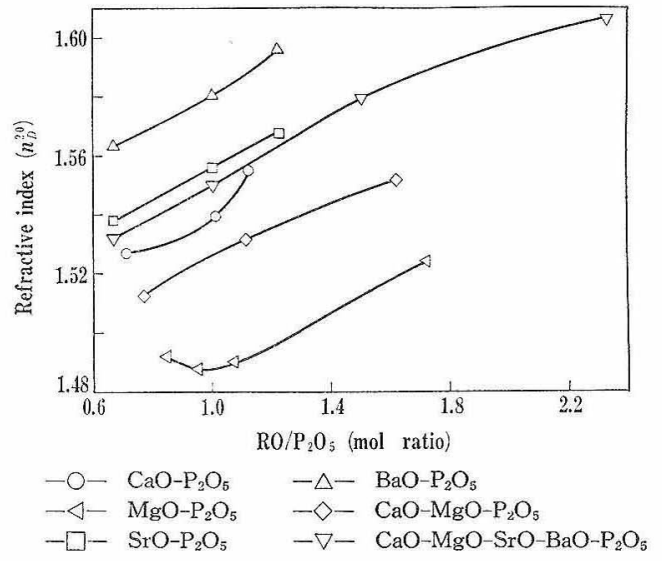

Fig. 5. Refractive index of some alkaline earth phosphate glasses.

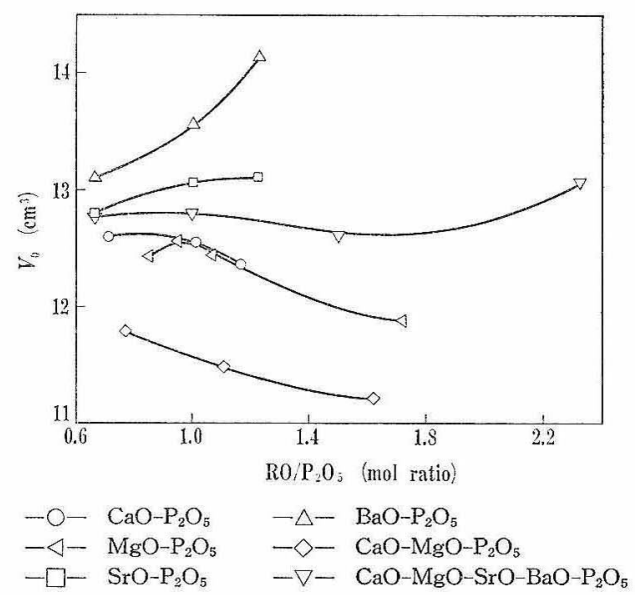

Fig. 6. Volume per gram atom of oxygen $\left(V_{0}\right)$ of some alkaline earth phosphate glasses.

MP 系洼高橋 ${ }^{3}$ ， Kordes ${ }^{5)}$, Elyard ${ }^{(1)}$ ，成瀨 ${ }^{10)}$ らによっ て指摘されているように，(RO+ $\left.\mathrm{H}_{2} \mathrm{O}\right) / \mathrm{P}_{2} \mathrm{O}_{5}=1$ 付近で anomaly点を百。虬し CMP, CMSrBP のように， 多種のカチオンをもつ系では，この MP 系の anomaly は消滅することがみとめられた。

アルカリ土類の影響としては，調べた R/P の範囲内 で密度, 屈折率の值は $\mathrm{BP}>\mathrm{SrP}>\mathrm{CP}>\mathrm{MP}$ の順で混 合系の值は，それを構成する単独カチオン系の中閒にあ る.ガラス体積は密度, 屈折率とは異尔り， Rにより変 化の様子が違っている。すなわち BP 系では R/P とと

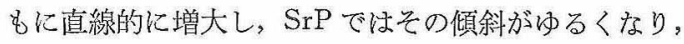
CMSrBP ではほぼ一定の值となる。CP, CMP 系のと きは逆に R/P 増大と共にガラス体積は減少する傾向を 示す。構造の充填化を現わすことがわかる，MP 系は密 度, 屈折率と同様に $\mathrm{R} / \mathrm{P}=1$ に anomaly を生じている。

ガラスで密度大，ガラス容樌小になるほど構造充填性 は大になるわけである。ところで図 -1 と図 $-4,5$ との双 方を対照すると，原則として充填構造になるほど塩酸溶
解性， $2 \%$ 枸涉酸溶解性は大きくなる.このことは 3.2 の考察の補足になる.ところが BP の栒椂酸溶解率（図 -1）は，比較的低いのに密度はとくに大きい，それがす なわち，3.2 で述べた表面の充填構造性の影響を示すも

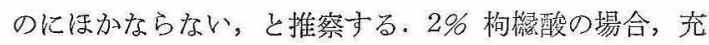
填の程度が非常に高いときには，このような栒楻酸分の 特性が，表面に出てくるように思われる。

\section{4 ペーパー・クロマトグラフィー}

図-7に CP, MP, 図-8に CMP, CMSrBP 各系のク ロマトグラムをそれぞれ示した，ETA 溶液にガラスを 溶解したとき, その粼酸イオンの分布ははとんど変化し ないと考えられている ${ }^{24)}$. 従ってこれらのクロマトグラ ムはそのまま, ガラス中のイオンの分布を示していると 考学る. 本実験上の制約から， $n \geqq 8$ ていどのイオンは 原点から移動せず分離困難なので, これらを⿱とめて八 イポリと呼び，またトリメタ，テトラメタの環状イオン をリングと略称して抒く. 分岐の橉酸は溶解後も仮にそ

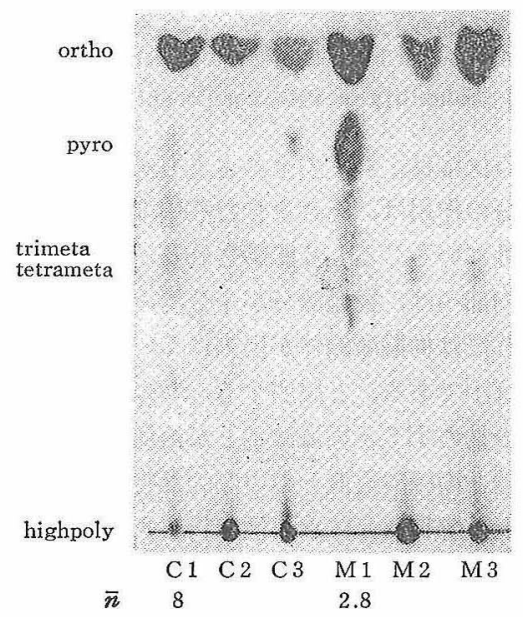

Fig. 7. Paper chromatograms of $\mathrm{CP}$ and $\mathrm{MP}$ glasses dissolved in $3 \%$ ETA solution.

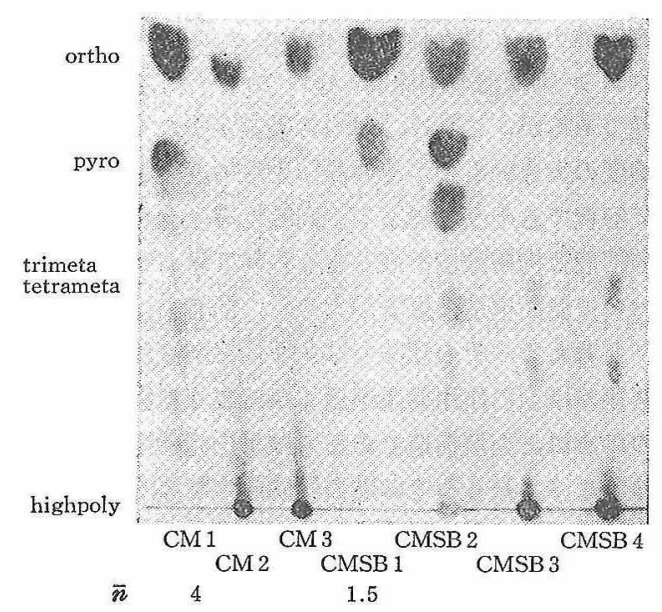

Fig. 8. Paper chromatograms of CMP and CMSrBP glasses dissolved in 3\% ETA solution. 
のますのかたちで存在しているとすれば，ハイポリと分 離されることなく，原点に位置しているものと思われ る. 図中試料番号の下の $\bar{n}$ は分析值から求めた理諭的な 䥊長である。

すでにアルカリ塩については見出されたことである が，すべての采に共通につぎの現象がみとめられた。(1) P/P 比增大にともない短鎻長イオンが增大寸ること, (2) オルトイオンが検出されること, (3) 組成から計算され る五中心にして広がった分布をもつこと，(4) リング 成分方少量認められること，(5) $\mathrm{R} / \mathrm{P} \fallingdotseq 1$ と $\mathrm{R} / \mathrm{P}<1$ と はほぼ同種の繗酸イオンを名つが $\mathrm{R} / \mathrm{P}<1$ の方がより 多量の八イポリを含んでいること，などである。

ガラス中の燐酸イオンの分布が融液中のそれをどの 程度代表しているがはだ十分明らかとはい㐬ない。 Meadowcroft $5^{26)}$ は，ガラス中の燐酸イオンの分布が 冷却速度によらず一定となったことからガラスに拈いて 見出された分布が融液中のそれであるとしている.しか し Meadowcroft らが採用した冷却条件は, 最も早いも のでも緩慢にすぎて分布が一定となった，とも考光得 る. 従ってガラス中での分布と融液中でのそれとの関連 については, 上り大きい泠却速度の場合の研究を待たね ばならない，現状では，問題にしている組成では融液中 のイオンの分布はガラスと同じか，岕るいはより短鎻側 によっているだろうとしか云えない、しかしいずれの場 合にもガラス中に見出されたオルト，ピロ，リングなど は, むともと融液中に存在したものの大部分放るいは一 部が，そのまま涷結残留したものと考えることができ る、それには水分による影響をまたあるものと思われ る.

これらのクロマトグラムのうら特に注目されるのは， CMSrBP 系の CMSB 1 老はじめとし, M 1 と CM 1 などの短鎻長のみに分布螌囲をもつものである. 試料溶 液化にともなう鎻長変化がほとんどないとすれば゙れ，ペ ーパー・クロマトグラムで観察されたイオンの大部分は

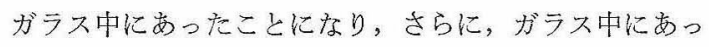
たイホンのほとんどは，大体そのままの形でクロマトグ ラムに現われる，と云って良い，そこで，これらのガラ スでは燐酸イオンの大部分がオルト,ピロのみであるか ら，結局 $\mathrm{Ca}, \mathrm{Mg}, \mathrm{Sr}, \mathrm{Ba}$ の各イオンとオルト，ピロの

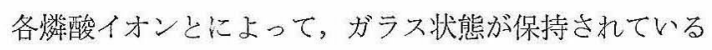
ことになる。

ETA 以外の溶版，すなわち水，N/5 塩酸， $2 \%$ 枸椂 酸，2\% 中性枸椂酸ナトリウム， $2 \%$ 水酸化ナトリウム に溶解させたものについてもペーパー・クロマトグラフ ィーを行なった．図-9に一例として N/5 盐酸に対する $\mathrm{CP}$ 系の溶解直後のクロマトグラムを示寸. 図-7 と図-9 とを比㬵すると ETA 溶解の場合とほとんど変らないこ とがわかる．他の溶剤の場合にも同様なことが観察され

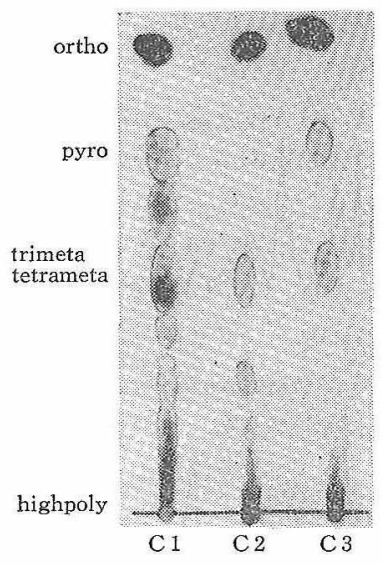

Fig. 9. Paper chromatograms of CP glasses dissolved in $\mathrm{N} / 5 \mathrm{HCl}$.

た. 枸彞䙲溶解によっ てもイオン分布はほ上 んじ変化を受けない， すなわち构椂酸に溶解 ナるためには鎻が切断 することを必要としな い. し加し溶解後の経 時変化をみると, 酸性 溶媒すなわら塩酸では 溶液を室温で 1 週問放 置すると，短鎻長への 移行が認められたのに 反し, 中性溶煤ではほ とんど変化がみられな かった.すなわち酸性 溶媒中では, 加水分解が速やかに進行するが，中性溶媒 中ではあまり進行しないことがあきらかである。

\section{5 失透物の $\mathbb{X}$ 線回折}

2.5 の方法により一部失透結晶化した試料の $\mathrm{X}$ 線回折 図を図-10〜12に，生成結晶種を表-3にまとめた。CP 系では $\mathrm{R} / \mathrm{P}=55 / 45$ に招いてトレメライト ${ }^{27)}$ と $\beta$ ーメ夕燐 酸カルシウム ${ }^{28)}$ の生成がみられ，50/50 抢よび 40/60 で は $\beta$-メ多憐酸カルシウムが生成した。この現象はほぼ 各系に共通で, MP 系では 60/40 でピロ粼酸マグネシウ ム ${ }^{29}$ が，50/50，40/60 では CP 系と同様メタ镂マグネシ ウム ${ }^{30)}$ が生成している。さらに SrP 系では 55/45 での結 晶は不明であったが，50/50，40/60ではともに $\beta$ ーメ夕橉 酸ストロンチウム ${ }^{311}$ が生成している. BP 系では，55/45
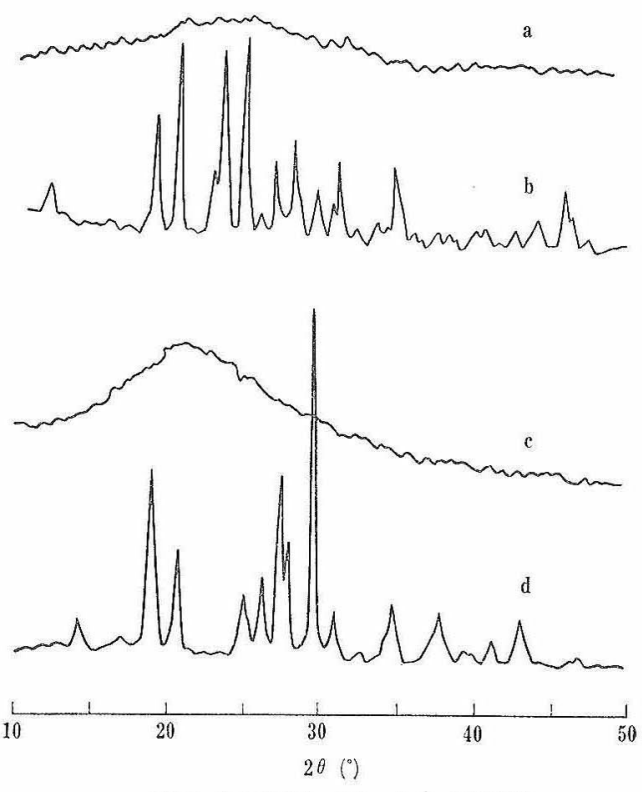

a : C $2, b: \mathrm{C} 2$ heat-treated at $700^{\circ} \mathrm{C}$ c : M 2, d : M 2 heat-treated at $825^{\circ} \mathrm{C}$

Fig. 10. X-ray diffraction patterns (No. 1). 


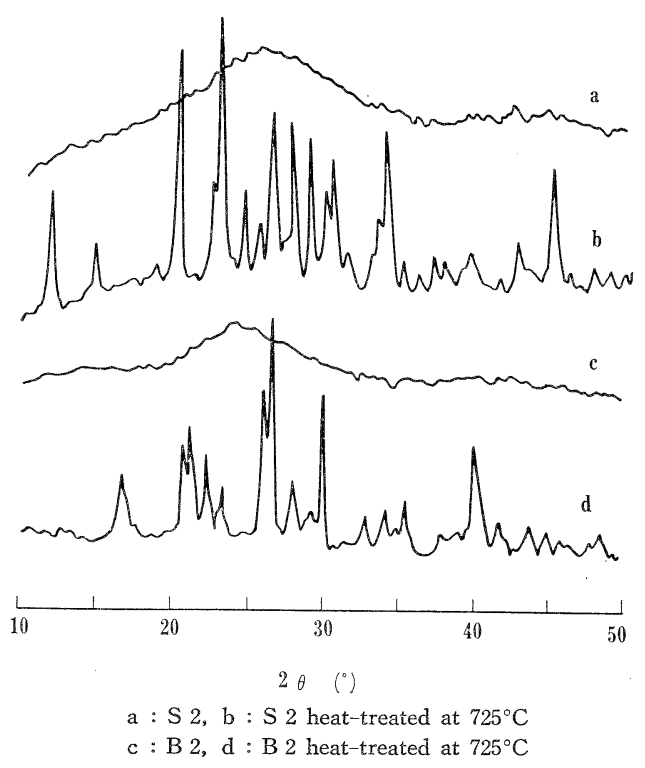

Fig. 11. X-ray diffraction patterns (No. 2).
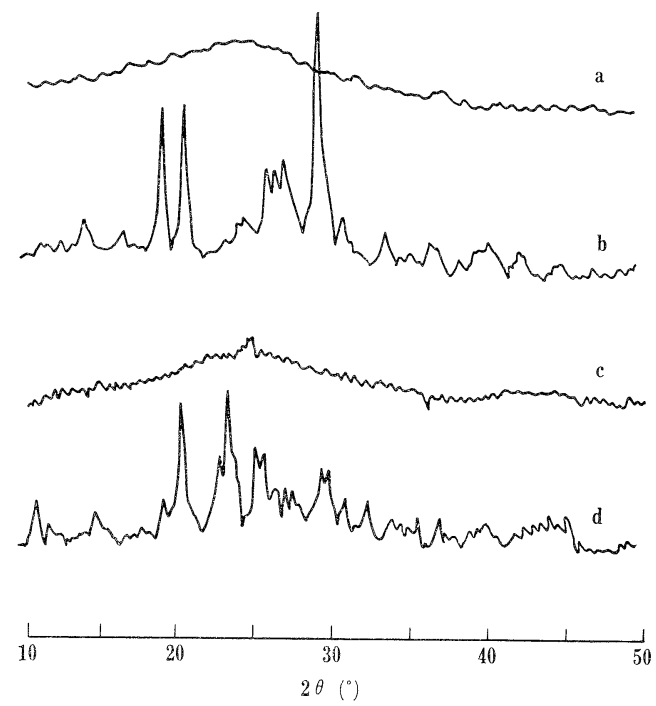

a : $\mathrm{CM} 2, \mathrm{~b}: \mathrm{CM} 2$ heat-treated at $755^{\circ} \mathrm{C}$

c : CMSB 3, d : CMSB 3 heat-treated at $790^{\circ} \mathrm{C}$

Fig. 12. X-ray diffraction patterns (No. 3).

のときメタ燐酸バリウム ${ }^{32}$ と未確認物質が，50/50 おう び 40/60ではメ夕燐酸バリウムが生成している. 混合力 チオンの CMP および CMSrBP 系の結晶化物は不明で ある・

失透結晶中には, $\mathrm{Al}_{2} \mathrm{O}_{3}$ 分を明確に構成成分として含 んだ物質は，発見されなかった．使用坩堝に由来する微 量 $\mathrm{Al}_{2} \mathrm{O}_{3}$ が，失透結晶種を大きく左右することはない ようである.しかし $\mathrm{Al}_{2} \mathrm{O}_{3}$ 分が他の各種結晶の生成し やすさに，若干影響するであろらことは考えてよい， $\mathrm{Al}_{2} \mathrm{O}_{3}$ の添加が一般にガラス製造上バッチのガラス化性 をよくすること，また著者の経験でも $\mathrm{CaO}-\mathrm{MgO}-\mathrm{P}_{2} \mathrm{O}_{5}$ $\mathrm{SiO}_{2}$ 系ガラスに $\mathrm{Al}_{2} \mathrm{O}_{3}$ を大れると, 製造時にガラス化
Table 3. Devitrification test of some alkaline earth phosphate glasses

\begin{tabular}{|c|c|c|}
\hline Symbol & $\begin{array}{l}\text { Temperature } \\
\text { of heat- } \\
\text { treatment }\left({ }^{\circ} \mathrm{C}\right)\end{array}$ & Crystalline substances identified \\
\hline C 1 & 745 & Trömelite, $\beta$-calcium metaphosphate \\
\hline $\mathrm{C} 2$ & 700 & $\beta$-calcium metaphosphate \\
\hline C 3 & 700 & $"$ \\
\hline M1 & 780 & magnesium pyrophosphate \\
\hline M2 & 825 & magnesium metaphosphate \\
\hline M 3 & 810 & $"$ \\
\hline S 1 & 725 & $\mathrm{X}^{\mathrm{a})}$ \\
\hline S 2 & 725 & $\beta$-strontium metaphosphate \\
\hline S 3 & 725 & " \\
\hline B 1 & 725 & $\mathrm{X}$, barium metaphosphate \\
\hline B 2 & 725 & barium metaphosphate \\
\hline B 3 & 725 & " \\
\hline CM 1 & 755 & $\mathrm{X}$ \\
\hline $\mathrm{CM} 2$ & 755 & $"$ \\
\hline CM 3 & 755 & $"$ \\
\hline CMSB 1 & 790 & $"$ \\
\hline CMSB 2 & 790 & " \\
\hline CMSB 3 & 790 & $"$ \\
\hline CMSB 4 & 790 & $"$ \\
\hline
\end{tabular}

a) unknown crystal

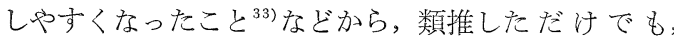
$\mathrm{Al}_{2} \mathrm{O}_{3}$ の存在は，ガラスが結晶化するときにそれを妨げ る役目を持つように，思える・したがって失透速度や失 透過程などを論じるときになればその影響を無視し得な いことになろう。

3.4 でみとめられ, さらに分析值でたしかめられたよ うに，C1 1 は $\bar{n} \fallingdotseq 8$ をあたえた。このガラスが結晶化に ともない鎻長の変化をあまりおこさなかったと考えれ ば，䥊長が短かい $(n \fallingdotseq 8)$ 部類のハイポリと, トレメラ イトとになることは十分あり得ることで，X線結果と一 致する. 従って同じ $\beta$-メタ燐酸カルシウムでも C 1 に おけるものと，C 2 ，C 3 のものとでは，燐酸の鎻長がか なり異なっているものと思われる。さらに MP 系に打 いても同様の 3.4 との一致がみとめられ，M1 におい てペーパー・クロマトグラフィーで最も多量の存在が確 認されたピロ・イオンからの結晶化がみとめられる。す なわちペーパー・クロマトグラムとの一致はかなり良 い. 従ってこれらのガラスの結晶化過程では燐酸イオン の鎻長変化はあまりおこらずそのまま結晶になる，すな わちガラス中に存在する短鎻燐酸イオンがそれをふくむ 燐酸塩結晶に変化すると考えられる. SrP , BP 系の R/P 大なるものから生じた結晶は，抎々らく $\mathrm{CP}$ 系のトレメ ライトに相当するような $n=3 \sim 5$ 程度の燐酸塩結晶と思 われる。また CMSB1 からの結晶は叔そらくピロ塩あ るいはオルト塩各結晶の混合物であるら。これら未確定 の結晶種についてはひきつづき検討中である。

3.6 燐酸イオンの形態とガラス化

3.4 で, 混合カチオン系ではオルト, ピロ・イオンの みからなる組成であっても，ガラスが得られたことを示 した、ここではその理由を考察する、燐酸塩の融液が泠 
却されガラスになる時, 次の二つの過程を経ると考えら れる. 第一は, 冷却過程で通過する各温度で種々の成分 間の反応がおこり, それらの進行の程度に応じたイオン の分布を示すに到るといら過程，第二は最初の過程で得 られた分布中の特定の成分が，その融点付近で，結晶化 をおこさないかどうかの過程である３.4 で述べたよう に，融液中のイオンの分布とガラス中のそれとははっき りした対応がつけられていない，従って最初の過程が実 際にあるのかどうか，およびあるとしたら泠却途中の各 温度で, 反応が平衡を保ちつつ進行しているか，などは 今後の問題であるら。しかし一般に, 燐酸塩ガラス中の イオンの分布は, 組成から理論的に求められた $n$ を中心 にしているから，主成分（通常 $n$ なる鎻長のイオンを含 む塩）の結晶化がみとめられるための量的な条件は，み たされていると推定する。従って融液が結晶化せずにガ ラスとなるためには, 二番目の過程が支配的であると思 われる。

第二の過程, すなわち特定の成分の結晶化を律するも のとしては, 数多くの因子が考光られる. それらは静的 なものおよび動的なもの，の二種に大別されよう．静的 な条件としては例えば, 網状結合の生成, 線状高分子の 特性などに由来する, 分子あるいはイオン内の原子がと り得る位置の数があり, 動的な例としては核生成, 結晶 成長などの速度過程がある. 勿論両者は密接に関連して いる. 例えば分子内原子の配置は原子間㧍よび分子間の 相互作用に関係し，その結果結合の交換，拡散などに影 響している。

燐酸塩では，鎻長が増大するととり得る配置の数が飛 躍的に大きくなり，容易にガラス化されるようになる. しかし本試料のようにオルト，ピロ・イオンのみを含む 場合には，この数は小さい值となり結晶化しやすくなる と思われる、従って短鎻橉酸イオンのみを含む組成から のガラス化では，速度過程が主な役割を果たしていると 考光る. 結晶生成の二つの速度過程, すなわち核の生 成, 結晶成長のどちらが抑光られ, ガラスとなったかは はっきりしない、しかし本試料には多種のカチオンがあ るために，両者に共通に含まれる因子である拡散が妨げ られ, 観察可能な結晶にまで成長し得なかった, と解釈 する．この解釈は短鎻燐酸塩がガラス化するために，多 種のカチオンが必らず必要だといらことを意味しない。 適当組成の合金は，急冷すればガラス質になる ${ }^{34)}$ すす わちこれらの物質では速度過程を抑制すれば，非晶のま ま常温にもち来たすことが可能である.従って燐酸塩に ついて考えれば，いわゆるネットワークを構成し得ない ようなオルト塩でも，条件さえ適当ならばガラス化可能 であると思われる，このとき条件は，多成分系にすると か，急冷するなどの方法により，二番目の速度過程を制 するようにえらべばよいことになる。

\section{4. 総括}

混合カチオン系もふくめた数種のアルカリ土類燐酸塩 ガラスを製造して, 溶剤溶解性およびその他の二, 三の 物性を検討した。すなわち, $\mathrm{CaO}-\mathrm{P}_{2} \mathrm{O}_{5}, \mathrm{MgO}-\mathrm{P}_{2} \mathrm{O}_{5}$, $\mathrm{SrO}-\mathrm{P}_{2} \mathrm{O}_{5}, \mathrm{BaO}-\mathrm{P}_{2} \mathrm{O}_{5}, \mathrm{CaO}-\mathrm{MgO}-\mathrm{P}_{2} \mathrm{O}_{\text {5 }}$ 㐨よび $\mathrm{CaO}-$ $\mathrm{MgO}-\mathrm{SrO}-\mathrm{BaO}-\mathrm{P}_{2} \mathrm{O}_{5}$ の各系について $\mathrm{RO} / \mathrm{P}_{2} \mathrm{O}_{5}$ モル比 が 0.7 1.7 のガラスの溶剤溶解性, ペーパー・クロマ トグラフィー, 失透結晶のX線回折図, 密度, 屈折率な ぞを測定検討し，構造化学的な解釈を行なった。扔もな 知見を以下に要約寸る.

1) $\mathrm{RO} / \mathrm{P}_{2} \mathrm{O}_{5}$ 比が大きいほど酸にたいする溶解率が 高くなる. 苛性ソーダではこの逆に, $\mathrm{RO} / \mathrm{P}_{2} \mathrm{O}_{5}$ が大き いほど溶解がわるくなる。中性溶剂（枸㘈酸ナトリウ ム, 塩化ナトリウム) では, $\mathrm{RO} / \mathrm{P}_{2} \mathrm{O}_{5} \fallingdotseq 1$ 亿溶解率の 極大がみとめられる。また $\mathrm{MgO}-\mathrm{P}_{2} \mathrm{O}_{5}$ ガラス法苛性ソ 一ダ溶解率が大きい。

2) $\mathrm{MgO}-\mathrm{P}_{2} \mathrm{O}_{5}$ ガラスのみ物性, 溶解性に特異性があ るが, 混合カチオン型にすると, その特異性は消失する. たとえば $\mathrm{MgO}-\mathrm{P}_{2} \mathrm{O}_{5}$ ガラスの密度, 屈折率の anomaly は $\mathrm{CaO}-\mathrm{MgO}-\mathrm{P}_{2} \mathrm{O}_{5}$ 系, $\mathrm{CaO}-\mathrm{MgO}-\mathrm{SrO}-\mathrm{BaO}-\mathrm{P}_{2} \mathrm{O}_{5}$ 系 ではみとめられない。

3）混合アルカリ土類の系では, 一般に高 $\mathrm{RO} / \mathrm{P}_{2} \mathrm{O}_{5}$ 比 までガラス化し, そのときの燐酸イオンとしてピロとオ ルトのみが検出された. またこの系のガラスの酸溶解率 は非常にたかい。

4）種々の溶媒に溶解したとき, 燐酸鎻長の変化はほ とんぞみとめられない。しかし酸性溶媒中では, 加水分 解がかなり早く進行する。

5）加熱失透に際して，鎻長をことにする燐酸イオン 間の反応は特にみとめられず，ガラス中に存在していた イオンの形態のままで結晶化が抗こると考えられる.

本報の内容の大部分は昭和 40 年 4 月 3 日, 日本化学会第 18 年会に掠いて講演 [講演番号 27321]した。

\section{文献}

1) E. Kordes, H. Becker, Z. anorg. chem. 260, 13 (1949).

2) C.F. Callis, J.R. Van Wazer, J.S. Metcalf, J. Am. Chem. Soc. 77, 1471 (1955).

3) K. Takahashi, "Advances in Glass Technology" Technical Papers of the VIth I.C.G. 366 (1962).

4) A.E.R. Westman, J. Crowther, J. Am. Ceram. Soc. 37, 420 (1954).

5) E. Kordes, W. Vogel, R. Feterowsky, Z. Elektrochem. 57, 282 (1953).

6) C.A. Elyard, P.L. Baynton, H. Rawson, Glastech. Ber. Sonderband, 32 K, VI 36 (1959).

7）成瀬 省, 阿部良弘, 名工大窝研報告 1，14（1963）.

8）並河 洋, 宗像元介, 窐協 73, 86 (1965).

9）並河 洋, 浅原慶之, 窝協 74, 205 (1966).

10）成瀬 省, 阿部良弘, 井上博義, 窯協 76, 36 (1968).

11）中村輝雄, “肥料分析法”養賢堂 (1962) p. 130.

12）文献 11）の p. 77

13）本島健次，日化 76,903 (1955). 
14）金沢孝文，川副博司，松原哲朗，日化会および化学関俰 学連合秋季大会講演予稿集 p. 69 [1 C 01] (1968).

15) D.N. Bernhart, W.B. Chess, Anal. Chem. 31, 1026 (1959).

16) M.K. Murthy. M.J. Smith, A.E.R. Westman, J. Am. Ceram. Soc. 44, 97 (1961).

17）金沢孝文, 工化 63，569（1960）.

18）金沢孝文, “溶成苦土リン肥に関卞る研究”熔成燐肥協会 (1961) p. 142.

19）金沢孝文, 伊藤力生, 工化 86, 686 (1963).

20）金沢孝文，石膏と石圧，No. 73，21 (1964).

21）金沢孝文，酒井清次，日化第 15 年会講演要旨集 p. 372 [No. 17408] (1962).

22）金沢孝文, 化学関係学協会 連合秋季研究発表大会 講演要 旨集 p. 83 [No. E 18] (1962).

23）金沢孝文，酒井清次，日化第 16 年会講演要旨集 p. 131 [No. 1 G 07] (1963).

24) S. Ohashi, J.R. Van Wazer, J. Am. Chem. Soc.
81, 830 (1959).

25) A.E.R. Westman, P.A. Gartaganis, J. Am. Ceram. Soc. 40, 293 (1957).

26) T.R. Meadowcroft, F.D. Richardson, Trans. Far. Soc. 61, 54 (1965).

27) W.L. Hill, G.T. Faust, D.S. Reynolds, Am. J. Sci. 242, 457 (1944).

28) A.O. McIntosh, W.L. Jablonski, Anal. Chem. 28, 1424 (1956).

29) ASTM X-Ray Powder Data File 11-40.

30) ASTM X-Ray Powder Data File 11-41.

31) R.C. Ropp, M.A. Aia, C.W.W. Hoffman, J.J. Veleker, R.W. Mooney, Anal. Chem. 31, 1163 (1959).

32) ASTM X-Ray Powder Data File 9-46.

33）金沢孝文, 工化 63，477（1960）; 文献 18）の p. 75 .

34) P. Duwez, R.H. Willens, Trans. Amer. Inst. Min. (Metall.) Engrs. 227, 362 (1963).

(10/15/1968 受付)

\title{
瑪瑙 の 研 究 \\ 岩井津一・小坂丈予・森川日出貴 \\ (東京工業大学)
}

\section{Study on Agate}

\author{
By \\ Shin-ichi IWAI, Joyo OSSAKA and Hideki MORIKAWA \\ (Tokyo Institute of Technology O-okayama, Meguro, Tokyo, Japan)
}

\begin{abstract}
Basic properties of domestic agate and of foreign agate were studied by an $\mathrm{X}$-ray method, polarization microscope, thermal analysis and emmission spectrochemical analysis. The agate is a family of quartz with minute amount of $\mathrm{Al}$ and $\mathrm{Fe}$ or $\mathrm{Mg}$ ions as ingredients without any bonding materials such as amorphous glass or opal. The agate held a small amount of structural water which was eliminated off at the temperature ranging from $400^{\circ} \mathrm{C}$ to $600^{\circ} \mathrm{C}$ on heating. The values of thermal expansions of agate in principal axes, which were determined by high temperature $\mathrm{X}$-ray diffractometer, were smaller than those of rock-crystal, especially in the direction of $c$ axis. The agate transformed into cristobalite below $1025^{\circ} \mathrm{C}$ and the corresponding activation energy of crystal growth were evaluated to be about $60 \mathrm{kcal} / \mathrm{mol}$. This value is smaller than that of siliceous stone. It was supposed that the broadning of five-fold lines in the vicinity of $68^{\circ}$ in $\mathrm{Cu} \mathrm{K}_{\alpha}$ radiation, the broadning of $\alpha-\beta$ inversion peak in DTA curves, the structural water and the size of crystallites in agate were closely related to each other.

[Received Dec. 3, 1968]
\end{abstract}

\section{1. 緒言}

珪酸鉱物の最も普遍的な鉱物種である石英には幾種類 かの変種が知られており，それらの一つに玉髄 (chalcedony) がある.この玉髄の中で特に带状の縞模様の著し いものは瑪悩 (agate) と呼ばれている. その中で色彩や 模㥞の美しいものは装飾品として古くから用いられてお り，また硬度が高いので，乳鉢・軸受などに使われてい る.瑪悩は通常繊維組織をなしている微細な石英よりな
り，火山岩の割れ目または空隚内に産出する。瑪琩につ いては従来多くの記載があり, 縞模様の形や色彩により 詳細な分類 ${ }^{1)} ゙$ なされているが, 光学的研究 ${ }^{2}$ や鉱物学的 研究はあまりなく，工業的利用の基礎となるような研究 もほとんどない。ここで著者らは，本邦ならびに諸外国 産の玉髄，瑪悩と呼ばれるものと，これに関連した低結 晶質玨酸鉱物と, さらに, 比較のための各種の石英とに ついて鉱物学的性状を検討した。瑪悩と呼壮れているも 